Sains Malaysiana 49(9)(2020): 2197-2210

http://dx.doi.org/10.17576/jsm-2020-4909-17

\title{
Improvement of Fatigue Resistance of Epoxy Composite with Heterogeneous Solid- State Self-Healing System
}

(Peningkatan Ketahanan Kelesuan Komposit Epoksi dengan Sistem Penyembuhan Diri Keadaan Pepejal Heterogen)

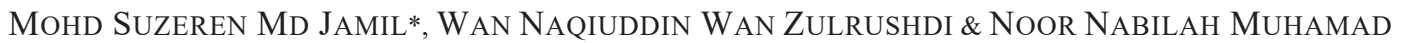

\begin{abstract}
The purpose of this research study was to investigate the improvement in fatigue life parameters and static strength residues of heterogeneous solid-state of the self-healing resin after exposure to fatigue cycles. The healing system is based on the thermoplastic-thermosetting semi-interpenetrating network. This system employs a thermosetting resin, into which a linear thermoplastic of poly(vinyl chloride) (PVC), poly(vinyl alcohol) (PVA), polyethylene (PE) or polypropylene (PP) as is dissolved. Upon heating a fractured resin system at a specific temperature, the heterogeneous resin blend undergoes a volumetric thermal expansion of healing agent within the matrix resin for crack recovery. Under the Compact tension (CT) test and within the third healing cycle, the modified resin with PVC has the average percentage recovery of 75-48\% compared with PP, PE, or PVA at around 67-31\%, respectively. The modified epoxy fatigue life with PVC and PP was shown to be increased by a factor of about 1.5 and 1.1 times after healing periods. The healable (modified) resin also showed an improvement in residual strength than the control resin after exposure to fatigue cycles. The fatigue-healing process was proven through the surface and cross-section resin morphology analysis using a microscopy optic and scanning electron microscope (SEM). On the whole, the heterogeneous solid-state selfhealing system has proven to be effective in obstructing fatigue crack propagation, effectively improved the self-healing polymeric material to achieve higher life extension.
\end{abstract}

Keywords: Fatigue life; healing agent; heterogeneous; residual strength; self-healing resin

ABSTRAK

Fokus penyelidikan ini adalah untuk mengkaji peningkatan dalam parameter jangka hayat kelesuan dan residu kekuatan statik bagi swapemulihan resin heterogen dalam keadaan pepejal selepas terdedah kepada kitaran muatan lesu. Sistem pemulihan ini adalah berdasarkan kepada penembusan/peresapan sebahagian rangkaian termoplastiktermoset. Sistem ini menggunakan resin termoset yang dilarutkan bersama termoplastik poli(vinil klorida) (PVC), poli(vinil alkohol) (PVA), polietilena (PE) atau polipropilena (PP). Apabila sistem resin yang mengalami keretakan dipanaskan pada suhu tertentu, campuran resin heterogen ini akan mengalami pengembangan volumetrik termal pada agen pemulihan dalam matriks resin untuk pemulihan keretakan. Di bawah ujian tegangan padat (CT) dan dalam kitaran pemulihan ketiga, resin yang diubah suai dengan PVC mempunyai purata peratus pemulihan tertinggi sebanyak 75-48\% berbanding dengan PP, PE, atau PVA pada 67-31\%. Kesan pemanjangan hayat kelesuan bagi resin yang diubah suai bersama PVC atau PP menunjukkan peningkatan dalam faktor masa sekitar 1.5 dan 1.1 kali selepas tempoh pemulihan. Resin pemulihan (terubah suai) ini juga menunjukkan peningkatan kekuatan bahan berbanding resin kawalan selepas didedahan kepada kitaran muatan lesu. Proses pemulihan kelesuan dibuktikan melalui analisis morfologi pada permukaan dan keratan rentas resin menggunakan mikroskop optik dan mikroskop elektron pengimbasan (SEM). Secara keseluruhannya, sistem swapemulihan resin heterogen dalam keadaan pepejal telah dibuktikan berkesan dalam menghalang penyebaran keretakan lesu dan dapat memperbaiki swa-pemulihan bahan polimer secara berkesan untuk peningkatan jangka hayat yang lebih tinggi.

Kata kunci: Agen pemulihan; hayat lesu; heterogen; kekuatan residu; swapemulihan resin

\section{INTRODUCTION}

Thermosetting polymers are susceptible to cracked growth under repeated loading. Fatigue is particularly problematic because it occurs at stress levels much lower than the critical stress intensity, $\mathrm{K}_{\mathrm{IC}}$ (Kim et al. 2019; Ye et al. 2017). The accumulation of damage degrades the mechanical performance and can lead to catastrophic failure of the material, especially those that fail in a brittle manner. To overcome these limitations, a new approach to the 'self-healing system' has been developed (Kanu et 
al. 2019; Michael et al. 2019). Polymeric self-healing has the ability to undergo recovery in the event of damage to the material using the source or the recovery agent that inherently available to the system. The self-healing system can be divided into two types, namely, extrinsic; without any external intervention (autonomously) (Lee et al. 2018; Zhang et al. 2018) and intrinsic; required external stimulus (Blaiszik et al. 2010; Urdl et al. 2017). Intrinsic systems of self-healing materials are based on thermally reversible reactions, hydrogen bonding, ionomeric coupling, a dispersed meltable thermoplastic phase, or molecular diffusion (Gyarmati et al. 2017; Michael et al. 2019; Zhang \& Guoqiang 2016). This nonautonomic system requires an external stimulus; such as thermo-mechanical, $\mathrm{pH}$, light or redox conditions, to trigger enhanced mobility and bond reformation in the damage region. These polymers have the ability to undergo repeated repair cycles even at the same crack or damaged area.

Intrinsic self-healing polymers based on the solidstate healable system have been studied extensively (Hayes et al. 2007; Jamil et al. 2015a, 2015b; Muhamad $\&$ Jamil 2016). The recovery system of heterogeneous healable resin is based on the concept of 'brick and mortar'; in which healing agents act as brick and resin act as mortar. The observed bleeding is attributed to volumetric expansion of the healing agent above its melting point in excess of epoxy brick expansion for crack recovery. These crack healing systems are time and temperaturedependent; and occur via void closure of 'free volume', surface interaction, or/and molecular entanglement between the damage faces (Blaiszik et al. 2010; Sharma et al. 2017; Zhang \& Guoqiang 2016). Using the same concept, Meure et al. (2012) used poly(ethylene-comethacrylic acid) (EMAA) thermoplastic as the healing agent in epoxy matrix materials. The EMAA can be dispersed as insoluble second-phase particles within the epoxy matrix phase. Upon heating, EMAA will force to flow or expand into cracks and other open flaws within the damaged material for recovery. Overall, these intrinsic healing mechanisms are thermally reversible for multiple healing events; even upon damage at the same site, and able to heal the cracks of different sizes and shapes (limited to small damage volumes) (Blaiszik et al. 2010; Murphy \& Wudl 2010). In other studies of heterogeneous self-healing systems, Luo et al. (2009) prepared a thermally remendable thermoset epoxy resin by dispersing immiscible or phase-separated 15.5 weight total percentage (wt. \%) poly(caprolactone) (PCL) in an epoxy matrix. In controlled thermal-mending experiments, heating (at $190{ }^{\circ} \mathrm{C}$ for $8 \mathrm{~min}$ ) of a cracked specimen led to PCL effusion from the bulk to yield a liquid layer bridging the crack gap. Muhamad and Jamil (2016) studied of heterogeneous solid state self-healing system by using different immisible thermoplastics as healing agents. Under compact tension test, this healable resin proved and able to demonstrate details self-healing capability of different specimens with the highest healing efficiency of between $70-40 \%$ within three healing cycle, respectively.

Characterization of fatigue response is more complex than monotonic fracture because it depends on many factors (Anja et al. 2020). Relatively few papers of healing of fatigue failure have been reported in the literature for polymeric materials. Earlier studies have shown that imparting self-healing capability to polymers and polymer composites leading to the retardation or permanent arrest of further fatigue crack propagation (Hamilton et al. 2012; Katunin \& Angelika 2017; Kim et al. 2019; Kostopoulos et al. 2019). Kim et al. (2019) studied crack healing in notched epoxy composite specimens using tensile fatigue tests. The stiffness could almost be fully recovered by the application of heat to trigger flow and polymerization of embedded microcapsules containing a mixture of EPA solvent and DGEBA epoxy healing agents. In addition, Brown et al. (2005) have made a first step towards a new crack healing methods for cyclic loading, demonstrated a fatigue loading response toward self-healing polymers based on microencapsulated healing agents. In this study, Grubbs' catalyst system was prepared, which was capable of responding to propagating fatigue cracks by autonomic processes that led to higher endurance limit and life extension, or even complete arrest of cracking (Anja et al. 2020; Awaja et al. 2016).

Despite some studies on fatigue crack propagation that have been undertaken on autonomic healing systems, there are no studies on the cyclic fatigue response towards solid-state healing (intrinsic) systems. Hence, the main aim of this investigation was to study the response of heterogeneous solid-state self-healing material towards fatigue failure through fatigue life and static strength residues parameters.

\section{EXPERIMENTAL DETAILS}

\section{MATERIALS}

For the production of matrix polymer or thermoset resin, diglycidyl ether of bisphenol-A (DGEBA) (with $\bar{M} w$ of of $384.36 \mathrm{gmol}^{-1}$ ), nadic methyl anhydride (NMA) and benzyldimethylamine (BDMA) are used as a resin monomer, anhydride curing agent and also as a cationic initiator for the ring-opening polymerization. All chemicals were obtained from Delta Resin Ltd and Sigma Aldrich Ltd. The composition of the epoxy-hardenercatalyst mixture is based on stoichiometric ratios of 100.0, 81.2 and 2.0. Polypropylene (PP) with $\bar{M} w$ of $12,000 \mathrm{gmol}^{-1}$, polyethylene (PE) with $\bar{M} w$ of 15,000 gmol $^{-1}$, poly(vinyl chloride) (PVC) with $\bar{M} w$ of 43,000 gmol $^{-1}$ and poly(vinyl alcohol) (PVA) with $\bar{M} w$ of 10,000 gmol $^{-1}$ obtained from Sigma Aldrich Ltd, was used as a healing agent. 


\section{MATRIX PREPARATION}

The modified or healable resin was prepared by heating the healing agent ( $8 \mathrm{wt}$. $\%$ of thermoplastic) and DGEBA at $90{ }^{\circ} \mathrm{C}$ for $24 \mathrm{~h}$ under the mechanical stirrer. The mixture was degassed at $90{ }^{\circ} \mathrm{C}$. NMA and BDMA were added and stirred for $15 \mathrm{~min}$ until it was completely dissolved. Again, the resin mixture was degassed at a temperature of $90{ }^{\circ} \mathrm{C}$ to eliminate air bubbles. The resin mixture was poured into a pre-heated silicone rubber bar mold before being cured (at $90{ }^{\circ} \mathrm{C}$ for $4 \mathrm{~h}$ ) and post-cure (at $150{ }^{\circ} \mathrm{C}$ for $1 \mathrm{~h}$ ) in an air convection oven. The neat (control) epoxy resin (contain no thermoplastic/healing agent) was also fabricated for comparative study purposed.

\section{MECHANICAL TESTING AND CHARACTERIZATION TENSILE AND COMPACT TENSION (CT) TEST}

The tensile properties of the bulk epoxies were determined according to ASTM-D638 (2003) and ASTM-D3479M (2003) test standard specifications, respectively. The schematic diagram showing the dimensions of the tensile test specimen is shown in Figure 1(a). All the tensile tests were performed using a $100 \mathrm{kN}$ computer-controlled screw-driven test machine, with a constant crosshead speed of $1 \mathrm{~mm} \mathrm{~min}^{-1}$.

Compact tension testing was performed to demonstrate the self-healing of the specimens. The samples according to BS-13586 (2000); with the dimensions shown in Figure 1(b), were prepared. A notch is machined into the specimen to ensure crack initiation and propagation. A small hole was drilled in the plane of the crack so that it would be arrested before final fracture. The sample was measured using Instron universal testing machine Model 5566 at crosshead speed $10 \mathrm{~mm} \mathrm{~min}^{-1}$, with $10 \mathrm{kN}$ load cell. Five replicate (tensile and CT sample) tests were conducted for each material. The percentage recovery $\left(\mathrm{R}_{\mathrm{K}}\right)$ of the sample was calculated based on the average of critical stress intensity factor $\left(\mathrm{K}_{1 \mathrm{C}}\right)$; which can be described in (1).

$$
R_{K}=\frac{100 \times K_{I C} \text { of the healed sample }}{K_{I C} \text { of the initial sample }}
$$

The resin healing efficiency, $H_{K}$ has been reestimated from (2), where $\mathrm{R}_{\mathrm{K}}{ }^{0}$ is the recovery percentage of (residual healing effect) control resin, respectively.

$$
\mathrm{H}_{\mathrm{k}}=\mathrm{R}_{\mathrm{k}}-\mathrm{R}_{\mathrm{k}}^{0}
$$

\section{FATIGUE TEST}

The fatigue test specimens were prepared with the same specific dimension as shown in Figure 1(a). The sharp edges of the bulk epoxy test specimens were smoothed with emery paper, before testing, to avoid any stress concentration effects. All the fatigue tests were carried out according to the ASTM-D3479M (2003) test standard specifications, using a $25 \mathrm{kN}$ computer-controlled servohydraulic test machine (Instron 8874). The tests were run at constant load amplitude (CA). A sinusoidal waveform of frequency $10 \mathrm{~Hz}$ was applied with stress (S) ratio, $\mathrm{R}$, of $0.1\left(\mathrm{R}=\mathrm{S}_{\min / \mathrm{Smax}}\right)$, where $\mathrm{S}_{\min }$ and $\mathrm{S}_{\max }$ denote the minimum and maximum values of the cyclic stress intensity, respectively) (Figure 2(a)). The tests were carried out with $50 \%$ of the ultimate tensile strength (UTS) of the material as a maximum stress level, $\mathrm{S}_{\max }$. Each loading condition was investigated with continuous cyclic loading to specimen failure and with or without a rest period to allow for healing (Figure 2(b)).

For the first test, both neat and modified (with healing agents) resin specimen was subjected to the loading. In order to establish the S-N curves, the tests were carried out until the specimen fails (complete fracture) or were terminated at 2 million cycles whichever occurred first. Then, the second loading test involved only modified resin. In this case, the sample was cyclic loading until the number of cycles was about 600 . Then, the specimen was taken out to be repaired or healed by heating in a circulating air oven at $160^{\circ} \mathrm{C}$ for $6 \mathrm{~h}$. The tensile fatigue test was also carried out to measure the changes in the tensile strength residues for the neat (control) and modified resin that was subjected to the cyclic loading; with and without healing cycles.

\section{CHARACTERIZATION}

Fourier transform infrared (FTIR) spectroscopy used in this study is the Spectrum ASCII PEDS 400 ATR Spectrometer from Perkin Elmer. The spectra were recorded at room temperature with an average signal of 64 scans at intervals of 2 and $16 \mathrm{~cm}^{-1}$ resolutions in the 4000-500 $\mathrm{cm}^{-1}$ infrared spectrum. Meanwhile, the dynamic mechanical properties of the samples were determined using a dynamic mechanical thermal analyzer (DMTA) of TA Instruments Thermal Analysis, DMA 2980. Measurements were performed in the singlecantilever bending mode. The spectra were collected from room temperature to $180{ }^{\circ} \mathrm{C}$ at a heating rate of $2 \mathrm{~K} \mathrm{~min}^{-1}$ and a single frequency of $1.0 \mathrm{~Hz}$. Surface morphological studies and cracking processes of resin matrix were performed using Optical Microscope. The microscope model used is the Axiolab A450909 Image Analyzer with Zeiss camera. The cross-sectional fracture surfaces from the fatigue tests of the bulk epoxy specimens were examined using a scanning electron microscope (SEM). The fracture surfaces were first sputter-coated with a thin layer of gold to prevent charging. Conventional secondary electron imaging conditions, with an accelerating voltage of $15 \mathrm{kV}$, were employed. 


\section{RESULTS AND DISCUSSION}

\section{FTIR ANALYSIS}

The concept of intrinsic crack healing depends on the random infiltration or diffusion of molecules in the thermoplastic to coat the cracked surface. FTIR-ATR was used to ensure that no interactions or FTIR-ATR is used to ensure that no interactions or chemical bonds are formed between the linear thermoplastic (healing agent) and matrix resin. Figure 3 shows the spectra of thermoplastic healing agents ( $\mathrm{PP}, \mathrm{PE}, \mathrm{PVC}$, and PVA), neat (DGEBA) resin and a modified resin containing $8 \mathrm{wt}$. $\%$ of PP, PE, PVC or PVA. As shown in Figure 3(a), the wave number of FTIR spectra of pure PP at 2950, 2867, $1458,1376,1167,997$, and $973 \mathrm{~cm}^{-1}$ were assigned to $\mathrm{CH}_{3}$ stretching, $\mathrm{CH}_{2}$ symmetric stretching, $\mathrm{CH}_{2}$ bending vibration, $\mathrm{CH}_{3}$ bending vibration, $\mathrm{CH}_{3}$ rocking vibration, and $\mathrm{CH}_{2}$ rocking vibration, respectively. Meanwhile, FTIR spectrum for PE at 2915, 2848, 1463, and 718.2 $\mathrm{cm}^{-1}$ were assigned to $\mathrm{CH}_{2}$ asymmetric stretching, $\mathrm{CH}_{2}$ symmetric stretching, bending deformation, and rocking deformation. PVC can be identified in the spectrum by its principal absorption bands, the $\mathrm{C}-\mathrm{H}$ stretching bands at $2,800-3,000 \mathrm{~cm}^{-1}$ and the $\mathrm{C}-\mathrm{Cl}$ stretching vibrations near $600 \mathrm{~cm}^{-1}$. These include the stretching of $\mathrm{C}-\mathrm{H}$ from $\mathrm{Cl}-\mathrm{CH}$ at $1,257 \mathrm{~cm}^{-1}$, the $\mathrm{C}-\mathrm{C}$ bond of the backbone chain at $1,072 \mathrm{~cm}^{-1}$, and the rocking vibration of $\mathrm{CH}_{2}$ at $958 \mathrm{~cm}^{-1}$. In addition, the FTIR spectrum of pure PVA presents a broad band at $3301 \mathrm{~cm}^{-1}$ is attributed to $-\mathrm{OH}$ stretching vibration; the peak at 1425 $\mathrm{cm}^{-1}$ is assigned to $\mathrm{OH}$ bending vibration of the hydroxyl group. The vibrational band at $2925 \mathrm{~cm}^{-1}$ corresponds to asymmetric $\mathrm{CH}_{2}$ group stretching vibration. The peak corresponding to $\mathrm{C}-\mathrm{O}$ stretching occurs at approximately $1089 \mathrm{~cm}^{-1}$ while the band at $842 \mathrm{~cm}^{-1}$ is attributed to the $\mathrm{C}-\mathrm{C}$ stretching vibration.

The curing reaction between anhydride and epoxy group in resins can also be observed by the infrared spectrum as shown in Figure 3(a). This reaction produced ester group with a clear peak at $1730 \mathrm{~cm}^{-1}$. Due to the opening of the epoxy ring from the curing process, the reduction in the intensity of the epoxy ring band at 915 $\mathrm{cm}^{-1}$ was observed. Throughout each modified resin (containing $8 \%(\mathrm{w} / \mathrm{w})$ of PP, PE, PVA or PVC) systems, the total wave number of FTIR spectra from each individual recovery agents (thermoplastic) and DGEBA resins can be clearly seen in Figure 3(b). This proves that the addition of linear thermoplastics to the resin matrix does not alter the chemical structure of the material with no new bond formation is formed specifically between the two materials.

\section{GLASS TRANSITION TEMPERATURE $\left(T_{G}\right)$}

DMTA analysis was conducted to determine the value of $T_{g}$ and the effect of the healing agent on the thermomechanical properties of the resin. $T_{g}$ was defined as the maximum in tan delta. Figure 4 shows the DMTA curves for the control and modified healable resins. The $T_{g}$ for neat/control resin appeared at $138{ }^{\circ} \mathrm{C}$ while for modified resins containing PVA, PP, PE, and PVC are $136,128,127$, and $132{ }^{\circ} \mathrm{C}$, respectively. In details, this temperature is representing as a $T_{g}$ of the matrix resin; in which the transition in the amorphous regions (from the semi-crystalline solid resin) between the glassy and rubbery state occurs. At this temperature, portions of the molecules would simply absorb the energy by momentarily deforming or stretching and can improve its flexibility.

The $T_{g}$ of healable resins with immiscible healing agent have been shifted. A secondary peak appeared for PVC at $84{ }^{\circ} \mathrm{C}$ and PVA at $94{ }^{\circ} \mathrm{C}$, and a broad peak in PP and PE curve. These values are not considerably dissimilar, and show that virtually all the linear thermoplastic is present in the DGEBA resin as a dispersed second phase. These phenomena represent the immiscibility of PVC, PVA, PP or PE in matrix DGEBA resin. Healable resins containing PVC, PVA, PP or PE are significant different compared to the unmodified resin, proving that these linear polymers are less compatible as linear-healing agent with the cured resin.

For self-healing system of a heterogeneous mixture separate phase, the recovery process involves the volumetric thermal expansion which closely related to the phenomenon of 'bleeding', where the recovery process should be done by heating the specimen to a temperature above thermoplastic melting point, $T_{m}$ which will cause spontaneous surface wetting by thermoplastic (Luo et al. 2009). In this study, $160{ }^{\circ} \mathrm{C}$ has been chosen as a healing temperature for all resins.

\section{COMPACT TENSION (CT) TEST}

CT test has been employed for the assessment of the selfhealing performance of the neat (control) and modified resins containing 8 wt. \% of PVC, PP, PE, or PVA. From the load to failure results (Figure 5), the percentage recovery $\left(R_{K}\right)$ and percentage of healing efficiency $\left(H_{K}\right)$ in compact tension strength after fracture in comparison to those obtained from the neat resin was calculated. Figure 5(a) shows that there is a low-level recovery effect with the percentage of recovery $\left(R_{K}\right)$ between the ranges of 5 to $2 \%$ in fracture toughness, for the neat resin after three times the healing cycle. This can be attributed to the possibility of a slight post-cure of the samples especially in the first healing cycle when the percentage recovery was at the highest or with the 'dangling' effect from the loose molecule during the healing process. The actual healing efficiency, $\mathrm{H}_{\mathrm{K}}$ was corrected based on the calculations shown in (2). Table 1 shows the corrected healing efficiency value of the modified resin (with all recovery agents) within the third healing cycles based 
on the results of the compact tension test. It was shown that modified resin containing PVC (Figure 5(b)) has the highest average corrected healing efficiency $H_{K}$ of $75-48 \%$ compared with $67-31 \%$ in a modified resin containing PP, PE or PVA (Figure 5(c)), respectively. Based on the healing efficiency results of the modified resin with different healing agents, PVC and PP were selected for further study.

\section{TEST STRAIN}

A static tensile test was carried out to obtain the maximum or ultimate tensile strength (UTS) which in turn will be used as a parameter in determining the value of the maximum stress in the fatigue test load. The stress-strain curves for the epoxy specimens were shown in Figure 6 . The average value of the UTS of the neat and modified (containing $8 \%(\mathrm{w} / \mathrm{w})$ of PVC or PP) resin obtained from static tensile test are 40.2, 40.8, and $37.2 \mathrm{MPa}$; in which five replicate tests were conducted for each set of material. The maximum tensile strength $\left(\mathrm{S}_{\max }\right)$ with $50 \%$ of the average UTS was used for the fatigue test. This is because of the sluggishness involving material damage when subjected to cyclic loading stress on the lower level of the ultimate static strength (Hamilton et al. 2012). Maximum stress values $\left(\mathrm{S}_{\max }\right)$ are 20.1, 20.0 and 18.6 MPa, respectively (Figure 6).

\section{FATIGUE LIFE AND RESIDUAL STRENGTH ASSESSMENT}

Typically, material fatigue performance characterized by the change in either the life cycle (number of cycles until the material fails) or crack growth. Although the parameters of crack growth are suitable for quantitative analysis of mechanical cracking, the number of life cycle remains vital in engineering applications as the life expectancy of all components, beginning with specimens in good condition, and micro fractures began under cyclic loading, subsequently spread to crack macro and finally creeping up failure end (Skinner et al. 2019).

Fatigue life $\left(\mathrm{N}_{\mathrm{f}}\right)$ of material is defined as the total number of stress cycles required to cause failure occurs. Figure 7 shows the result of the cycle of failure, $\mathrm{N}_{\mathrm{f}}$ for the neat (control) and modified resin (with PVC and PP) by graphing changes in force, $\mathrm{F}_{\text {min }}$ against the number of cycles, N. The number of cycles that have been obtained are summarized in Table 2. Based on the total number of fatigue cycles obtained, it is clear that the fatigue life of the modified resin (with PVC and PP) applied with four/ five times the recovery process exceeds 1.5 and 1.1 of the fatigue lives of the control resin. The results obtained indicated that the fatigue life of the resin matrix with the heterogeneous solid-state self-healing system is longer compared to the epoxy (neat) resin matrix without this recovery system.

Fatigue loading criteria can be classified into four major categories: macroscopic fatigue strength criterion, criterion based on residual strength, criteria based on the residual stiffness and finally criteria based on actual damage mechanisms (Katunin \& Angelika 2017). In this study; in addition to comparing with the number of cycles of fatigue life $\left(\mathrm{N}_{\mathrm{f}}\right)$, the effect of solid-state self-healing systems on fatigue was also identified by comparing the changes in the tensile strength residues for the neat and modified resin. Degradation of residual tensile strength with the number of cycles for the control and modified resin; with and without the recovery process, is plotted in Figure 8 and summarized in Table 3. Average residue tensile strength $(\mathrm{MPa})$ for the neat and modified resin after 600 fatigue cycles are plotted in Figure 8(a). It shows that the relationship between the degradation of the tensile strength and the number of fatigue cycles. It can be observed when the matrix resin is charged with fatigue stress up to 600 cycles, the average residual strength of the material has dropped for all resins from around 40 to 24-26 MPa (Table 2). Given the residual tensile strength is almost similar to the neat and modified resin, it can be said that the addition of healing agents in an epoxy resin matrix does not affect the properties of fatigue. In contrast, the residual strength of modified resin that undergoes recovery after 600 cycles were found to be higher ( $\sim 36 \mathrm{MPa}$ ) (Figure $8(\mathrm{~b}))$ than the control modified resin strength residues (without the healing process). Overall, the modified resin strength residue charged with the healing process was also found to decrease at a slower rate throughout the load cycle up to 3000 fatigue cycles. However, in comparison with modified resin containing PVC, residual strength of modified resin that containing PP was seen descending quickly within 3000 fatigue cycles and after the healing process (Table 3 ). These results were in agreement with the performance in fatigue life $\left(\mathrm{N}_{\mathrm{f}}\right)$ of material from the total number of stress cycles required to cause failure in resins.

Based on the comparison with the neat and modified resin's fatigue life, it is clear that heterogeneous solidstate self-healing resin systems showed an improvement in fatigue life parameters, $\mathrm{N}_{\mathrm{f}}$ and static strength residues due to the healing effect after exposure to fatigue cycles. The 'brick and mortar' concept (Meure et al. 2012) was used in the recovery system of heterogeneous solidstate self-healing resin with the immiscible healing agent (PVC or PP). As heating the system, the healing agent (act as a brick) will undergo volumetric thermal expansion and viscous flow above its melting point in excess of epoxy expansion (act as a mortal); as shown in Figure 9. Upon cooling, the formation and precipitation of PVC or PP crystals occur and subsequently act to cover the cracked surface area and restore the mechanical strength of the material.

Meanwhile, in comparison with modified resin with PVC, the rate of reduction of healing efficiency in heterogeneous resin with PP was higher. This is most 
likely due to the uneven dispersion of phase separation in PP-resin mixtures which results in reduced healing efficiency. Although the effects of phase separation through the concept of brick and mortar are required in the heterogeneous healing system, even dispersal or uniformly dispersed of immiscible healing agents is required (Figure 10(a)). The irregular shapes and broadly distribution size of healing agents in the system somewhat affect the thermal expansion mechanism in the healing process (Figure 10(b)). The probability is high for fractures occurring in areas where no healing agent is available for recovery through the volume expansion method and this will result in a significant reduction in material recovery capabilities.

Overall, although there was an improvement in resin's fatigue life due to the healing recovery, the reduction in healing efficiency, residue strength and fatigue life parameters were also recorded after exposure to fatigue cycles and repeated healing. It is suggested that a reduction in the healing efficiency of the resin after repeated healing cycles is mainly due the possibility of physical aging effect which is related to the reduction in the fraction of free volume through the chain conformation or compaction of matrix resin. Future studies need to be done to clearly identify the effect of reduction in healing efficiency of resin.

\section{MORPHOLOGY STUDY}

Self-healing ability of the resin matrix due to micro cracking caused by fatigue test have been analyzed using optical microscopy and SEM. Optical microscopy was used to study the self-healing ability on the surface of the resin matrix while SEM was used to study the cross surface of the resin matrix that was experiencing fatigue cracks. Figure 11 shows micrograph on the surface of modified resin that has undergone a fatigue test. Fatigue cracks can be clearly seen on the sample surface (Figure 11(a)). Micrograph of modified resin (containing PVC or PP) specimens, before and after the recovery is shown in Figure 12(b). Fatigue crack on the specimen surface was exposed to stress after 600 cycles of fatigue (Figure $11(\mathrm{~b})_{1,3}$ ) with $50 \times$ magnification. Both resins (Figure $11(\mathrm{~b})_{2,4}$ ) show that the fatigue crack had been restored after the healing process at $160{ }^{\circ} \mathrm{C}$ for $6 \mathrm{~h}$.

In general, fatigue is a type of dangerous and hidden failure that occurs without warning. The investigation on the effect of fatigue on the crack surface of matrix resin was observed. The micrograph of fully fracture fatigue crack surface specimen is studied and shown in Figure 12. Fatigue cracking surfaces of matrix resins indicated outer nominal morphology. In agreement with the schematic concept of a typical fatigue-fracture matrix surface (Figure 12(a)), the matrix resin shows that fatigue cracked start from the surface of the matrix and slipped into specimens in a semi-elliptical form, i.e., thumbnail, shaped crack (Figure 12(b)). Fatigue processes occur at the onset of cracking and are followed by crack propagation, and usually, the fractured surface is perpendicular to the direction of the applied stress. According to the general observation in polymers (Kullmer et al. 2016), regions such as slender mirrors were characterized by early fatigue crack growth regions, which were followed by relatively rough radius, and fastfracturing regions. The surface of the resin matrix's that experienced fatigue cracks were also examined using an SEM as shown in Figure 12(c). River markings sign has been observed on the surface of the resin matrix. They show the direction of progression of the fatigue cracks. River marks emerge most frequently in the relatively fast-growing sections of the fatigue zone, and, other than indicating the direction of cracked growth, they supply little information that can be used to diagnose the cause of the failure (Hirschberg et al. 2019). (a)

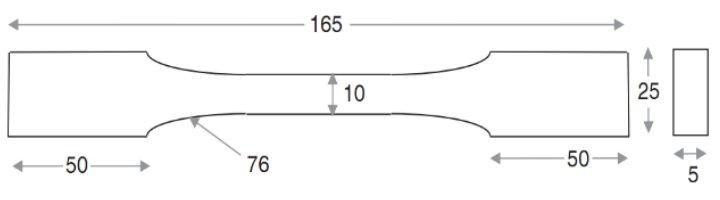

(b)

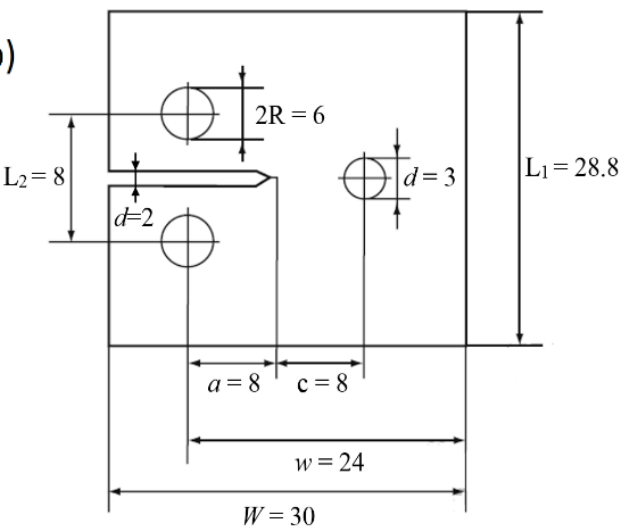

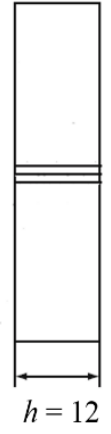

$h=12$

FIGURE 1. Schematic diagram showing the dimensions of

(a) the tensile/fatigue and (b) compact tension test specimens of bulk epoxy polymer (in $\mathrm{mm}$ ) 


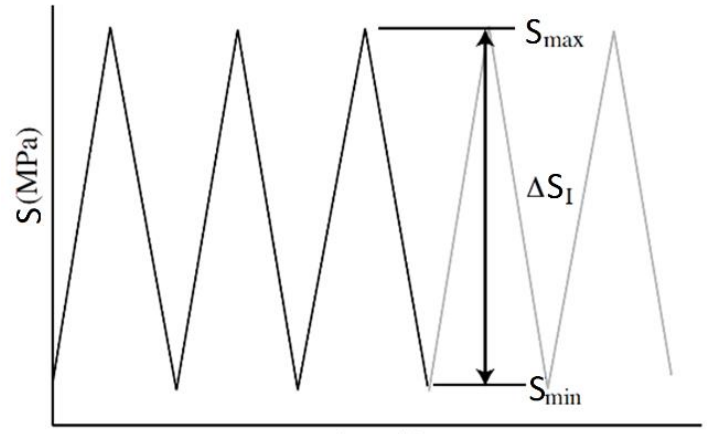

time (s)

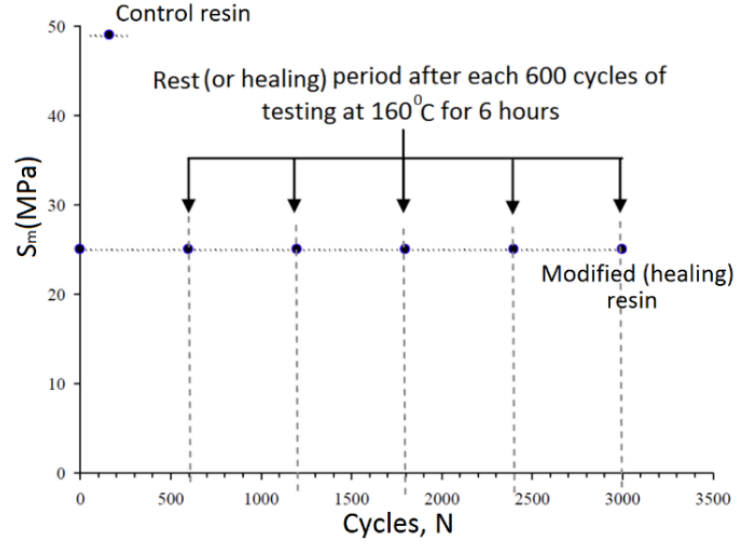

FIGURE 2. Schematic of (a) fatigue life test under fatigue loading parameter (frequency $10 \mathrm{~Hz}, \mathrm{R}=0.1$ ) with (b) the healing or rest/resting period for every 600 cycles

(a)

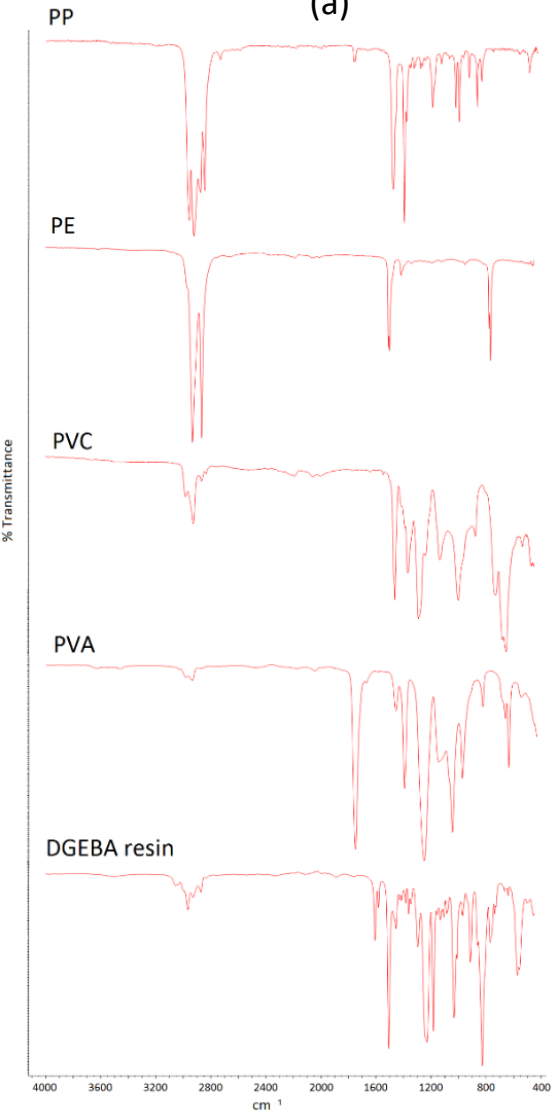

(b)

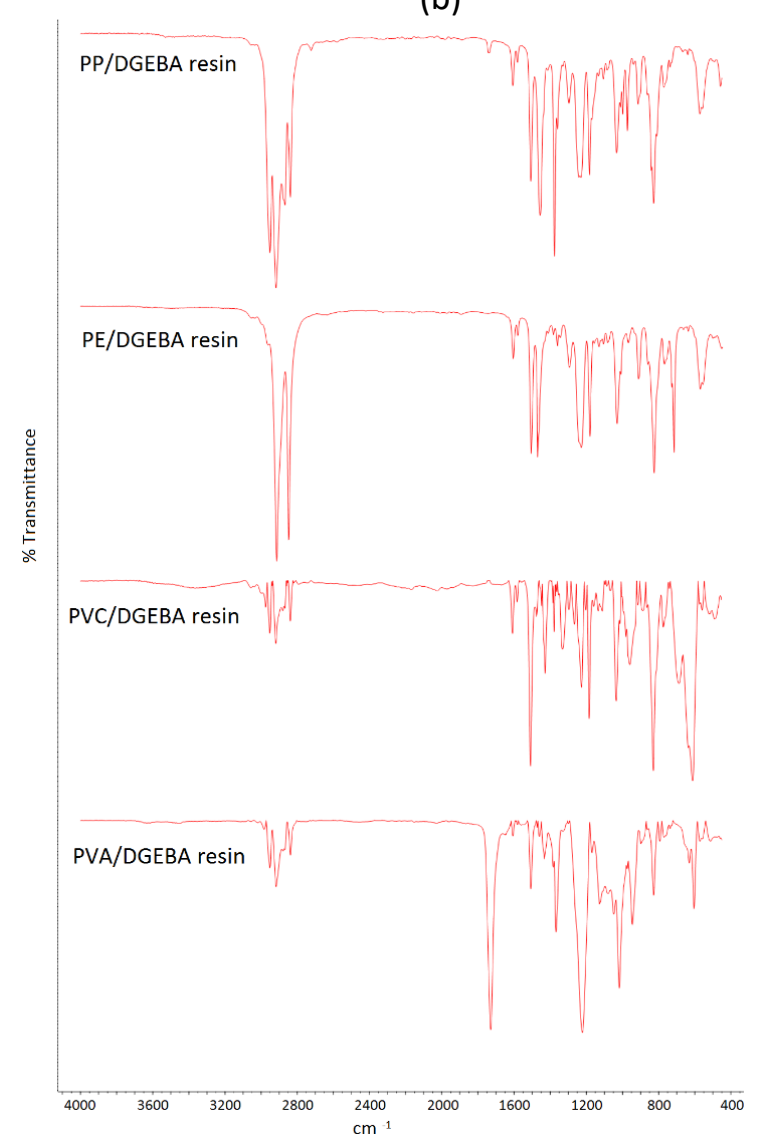

FIGURE 3. FTIR spectra of (a) PP, PE, PVC, PVA, neat (DGEBA) resin and (b) modified resin containing $8 \%(\mathrm{w} / \mathrm{w})$ of PP, PE, PVA or PVC 


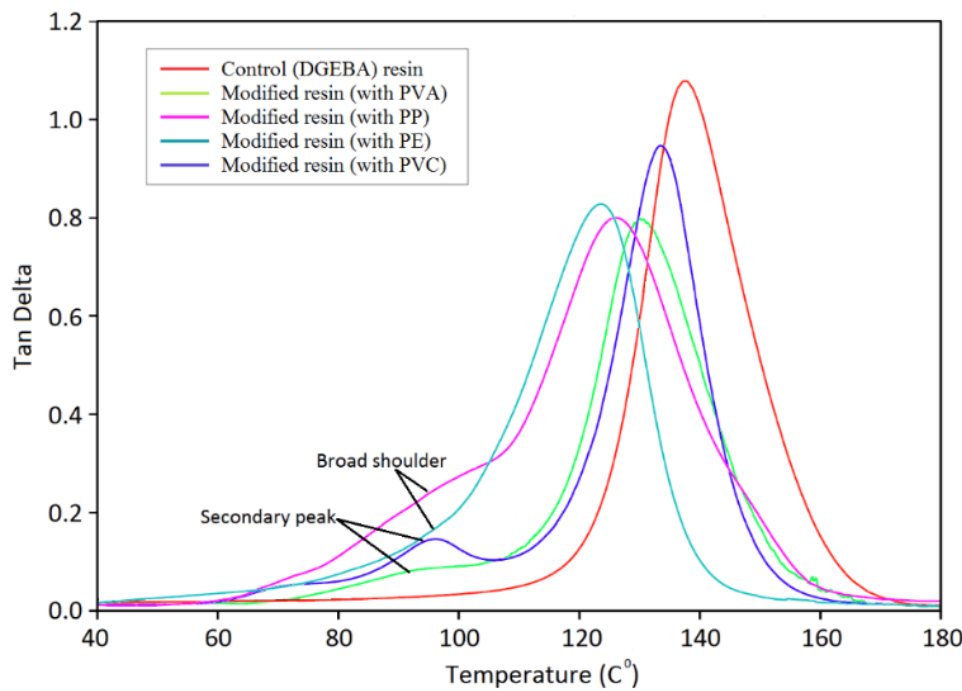

FIGURE 4. DMTA traces for the neat and modified resin containing $8 \%(\mathrm{w} / \mathrm{w})$ of PVA, PP, PE or PVC

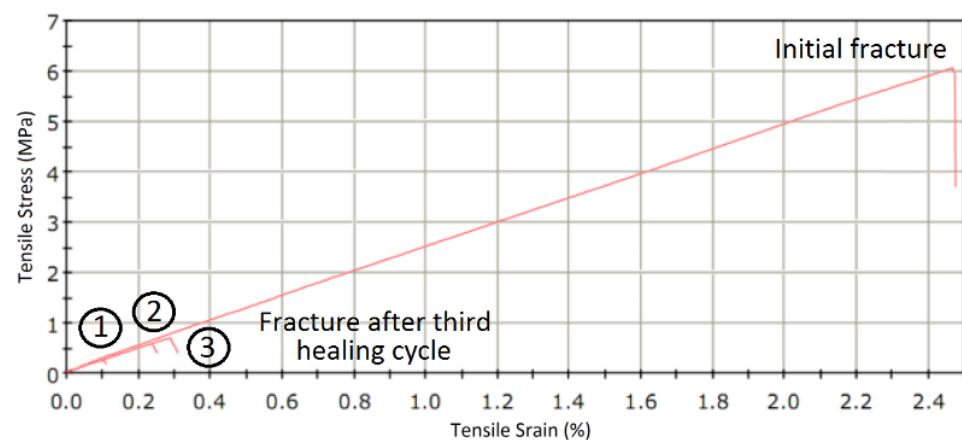

(a)

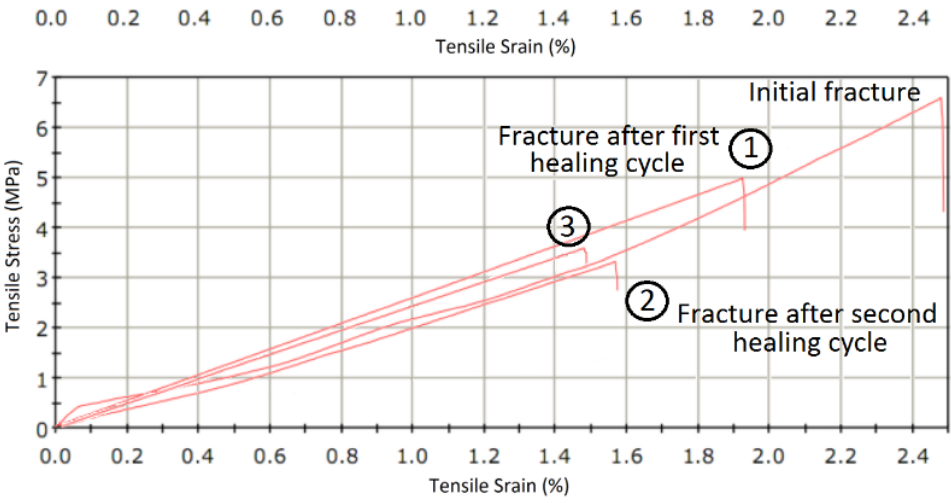

(b)

FIGURE 5. The stress-strain curves of repeated healing of (a) neat DGEBA resin and (b) modified resin containing PVC, from the compact tension test. The samples were healed at $160{ }^{\circ} \mathrm{C}$ for $6 \mathrm{~h}$ in each healing cycle 

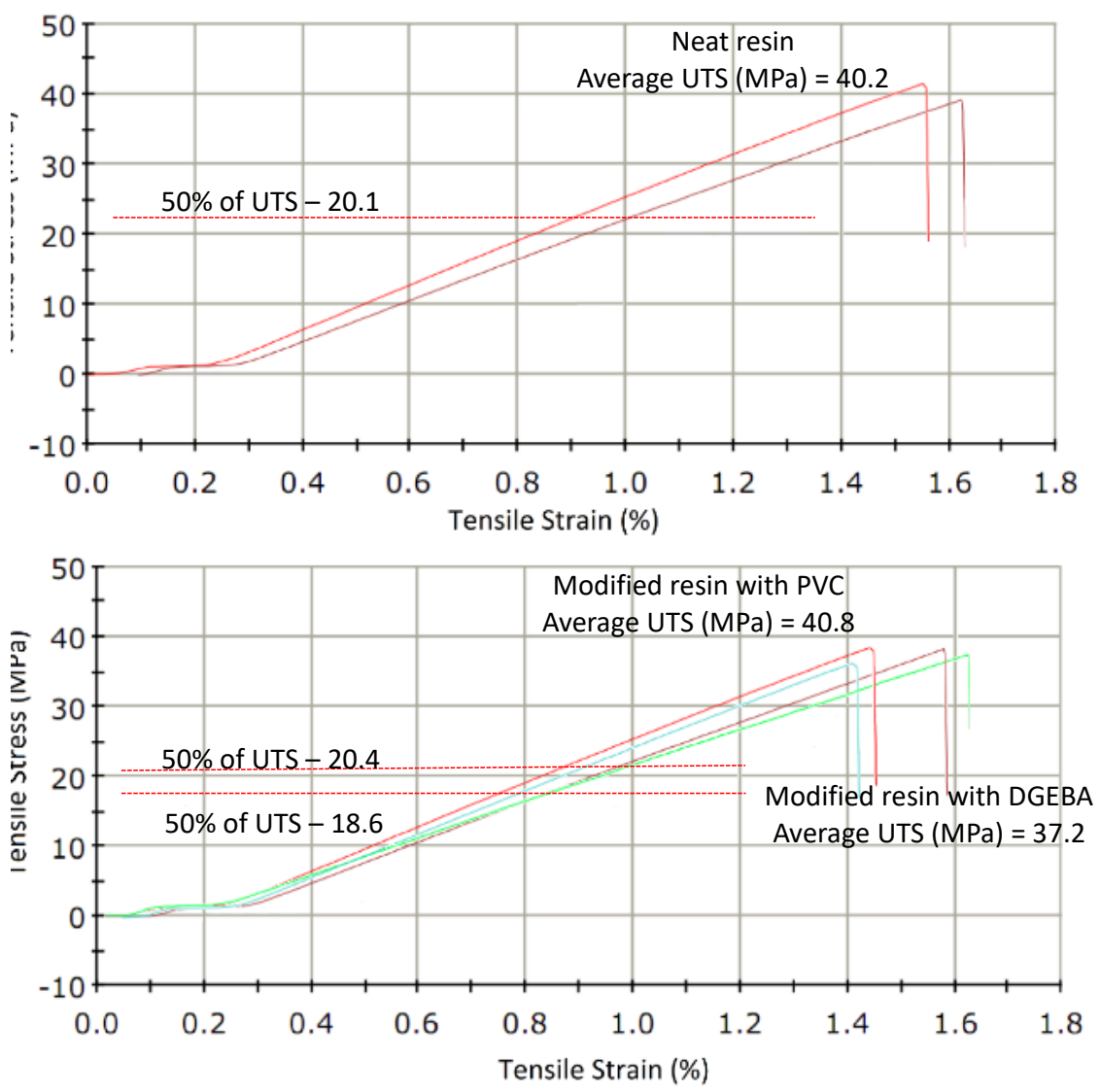

FIGURE 6. The stress-strain curve of (a) neat and (b) modified epoxy containing $8 \%(\mathrm{w} / \mathrm{w})$ of PVC or PP. Five replicate tests were conducted for each set of material for average value of ultimate tensile strength (UTS)

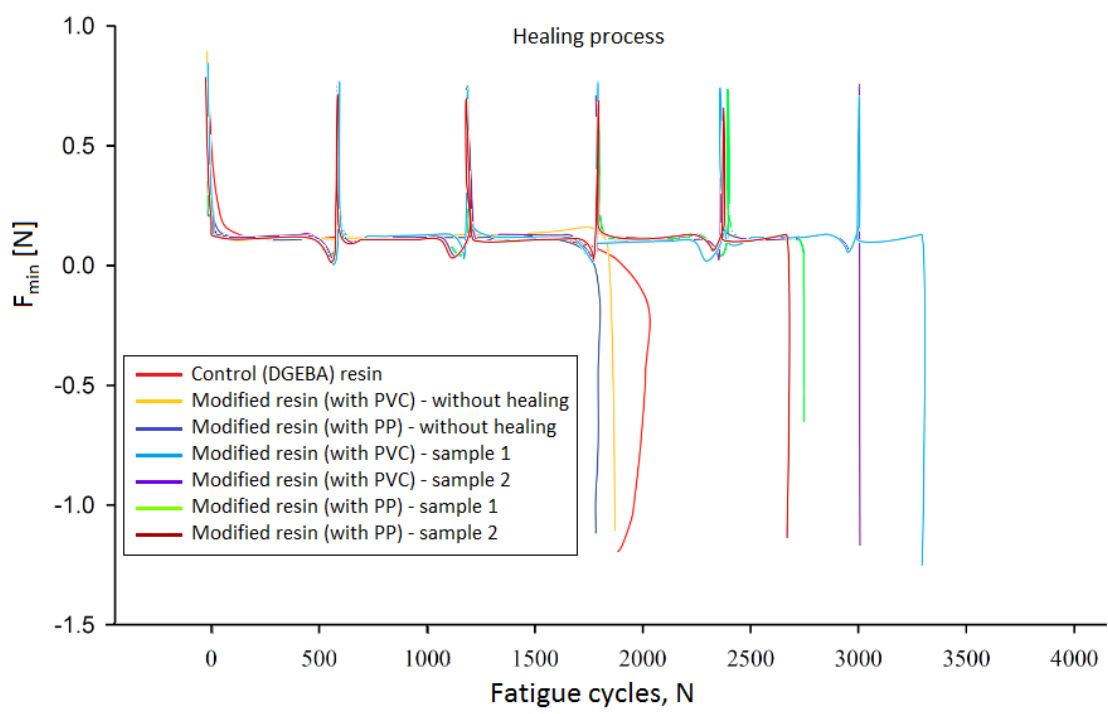

FIGURE 7. Graph of change in force $\left(\mathrm{F}_{\min }\right)$ versus the number of fatigue cycles $(\mathrm{N})$ for the neat (control) and modified resin containing $8 \%(\mathrm{w} / \mathrm{w})$ of PP or PVC; with and without healing process. Rest (or healing) period after every 600 cycles of testing at $160{ }^{\circ} \mathrm{C}$ for $6 \mathrm{~h}$ 


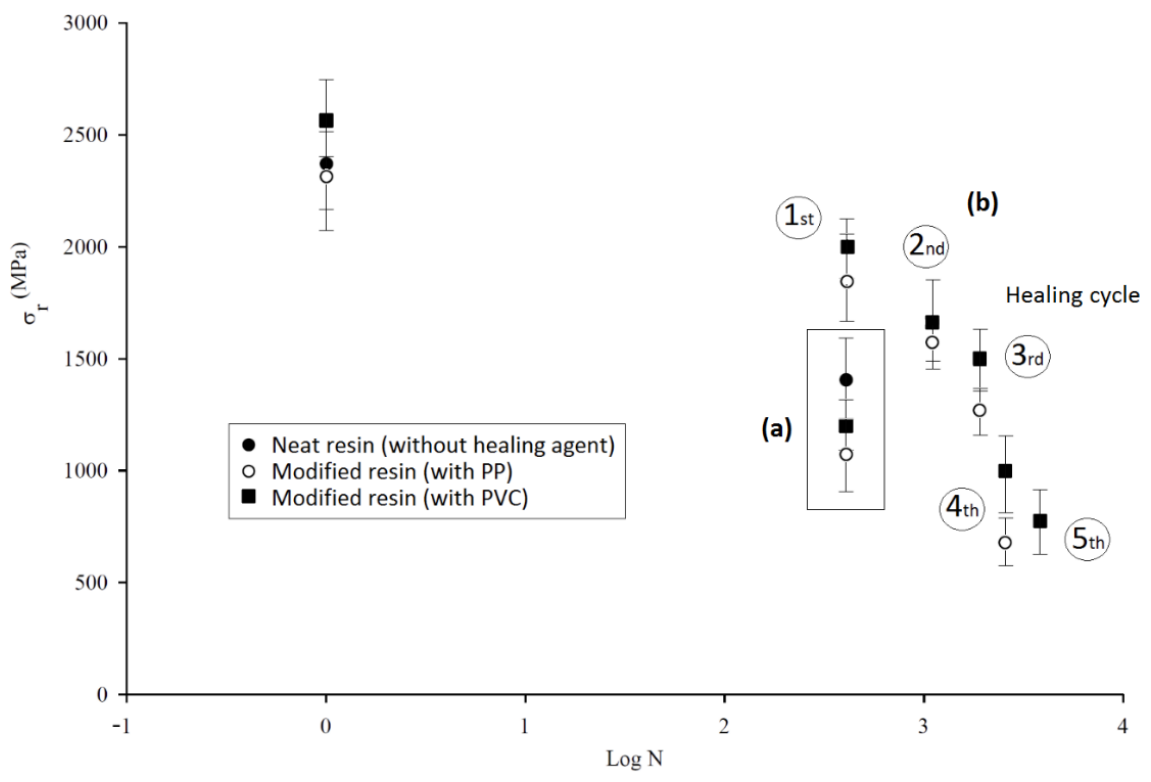

FIGURE 8. Residual strength for the neat and modified resin after (a) 600 cycle of fatigue test or (b) with the healing process for each 600 cycles of fatigue test; with $\sigma_{\mathrm{a}}=50 \% \sigma_{\mathrm{o}}$

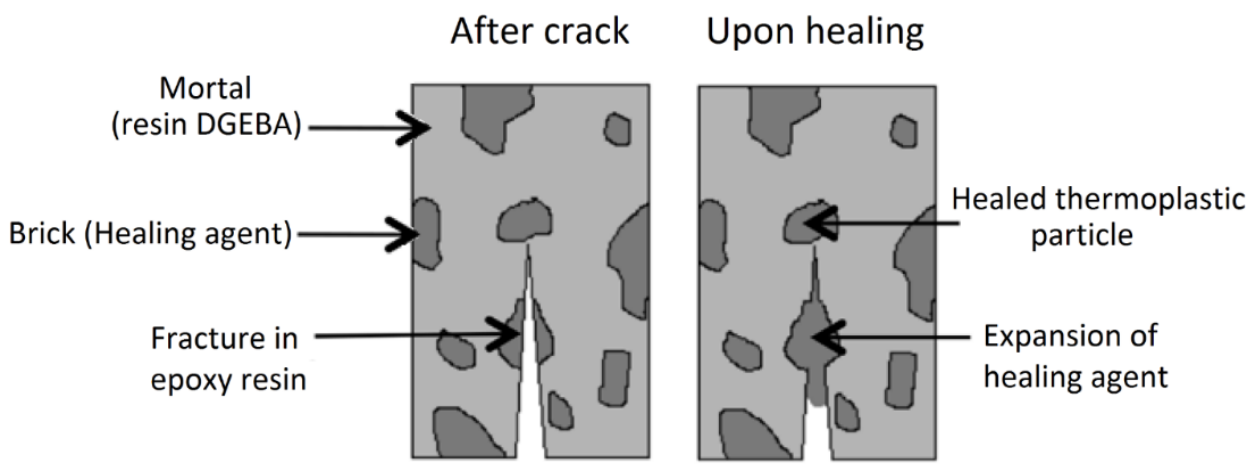

FIGURE 9. Recovery mechanisms in the concept of heterogeneous solid-state healing resins

(a)

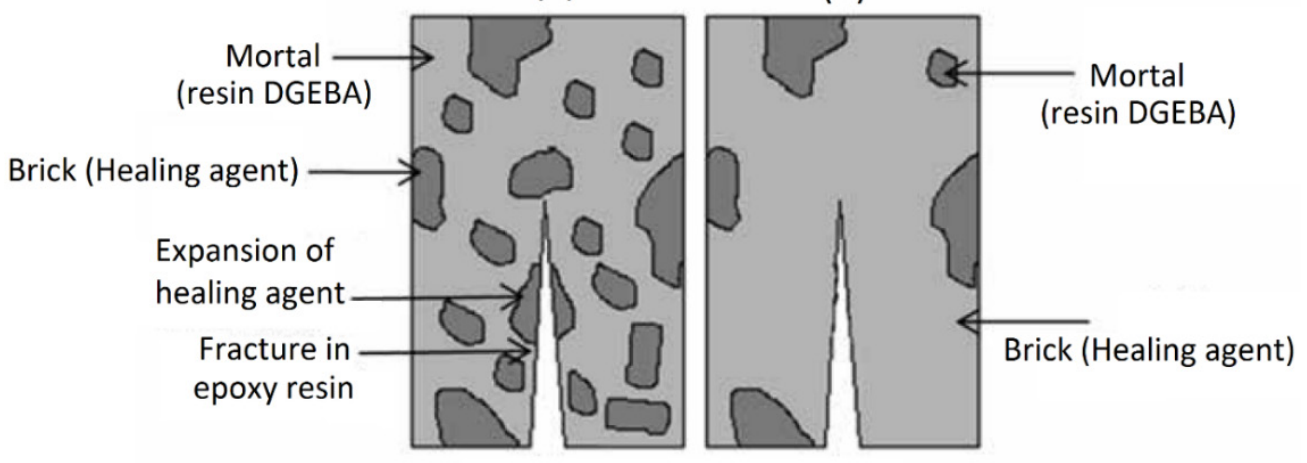

FIGURE 10. The concept of bricks and mortar in heterogeneous recovery resins in which recovery agents can be dispersed (a) evenly and (b) uneven 


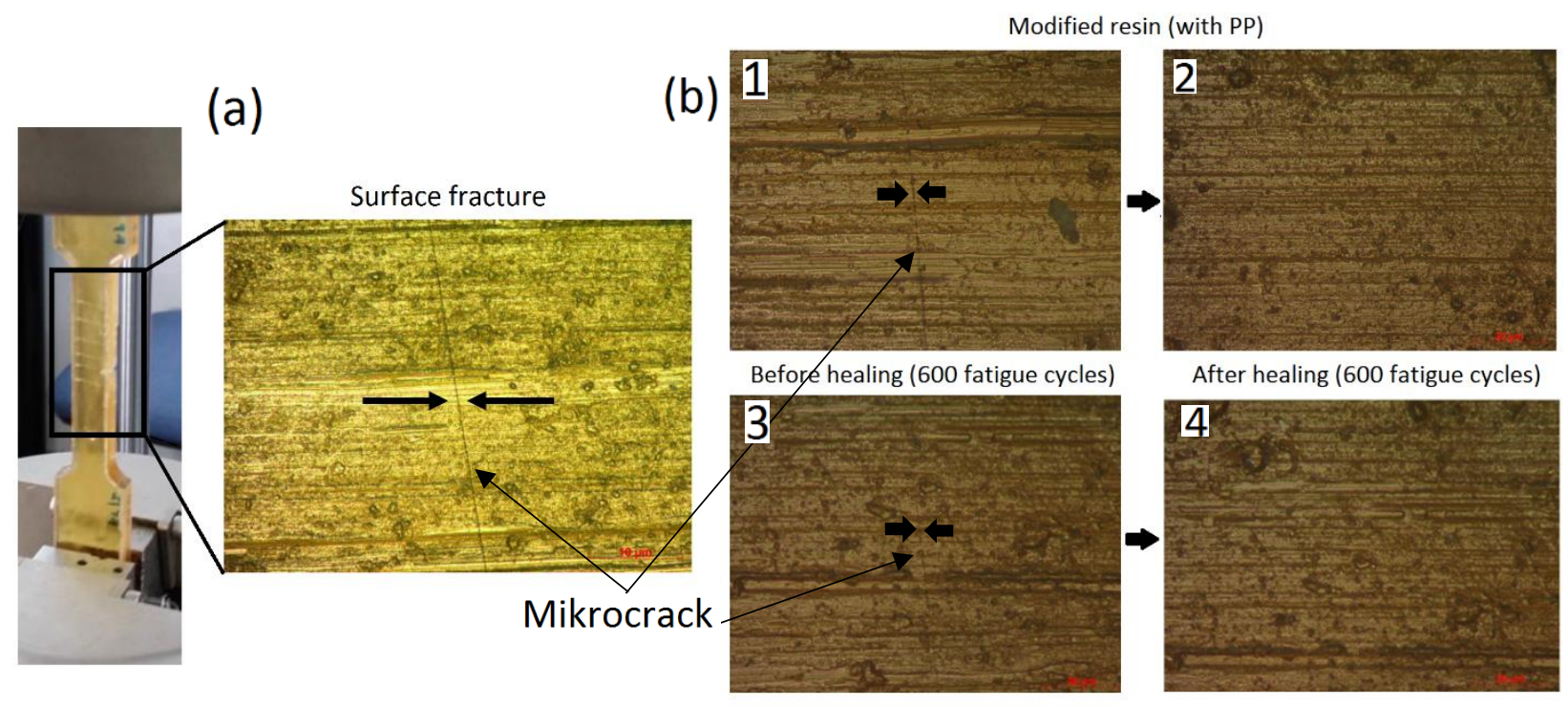

Modified resin (with PVC)

FIGURE 11. (a) Micro cracking micrograph on the surface of the modified resin matrix during the fatigue strain test is carried out (Scale bars are 10 $\mu \mathrm{m})$ and (b) after being subjected to the healing cycle; before $(1,3)$ and after $(2,4)$ the recovery process (Scale bars are $20 \mu \mathrm{m}$ )
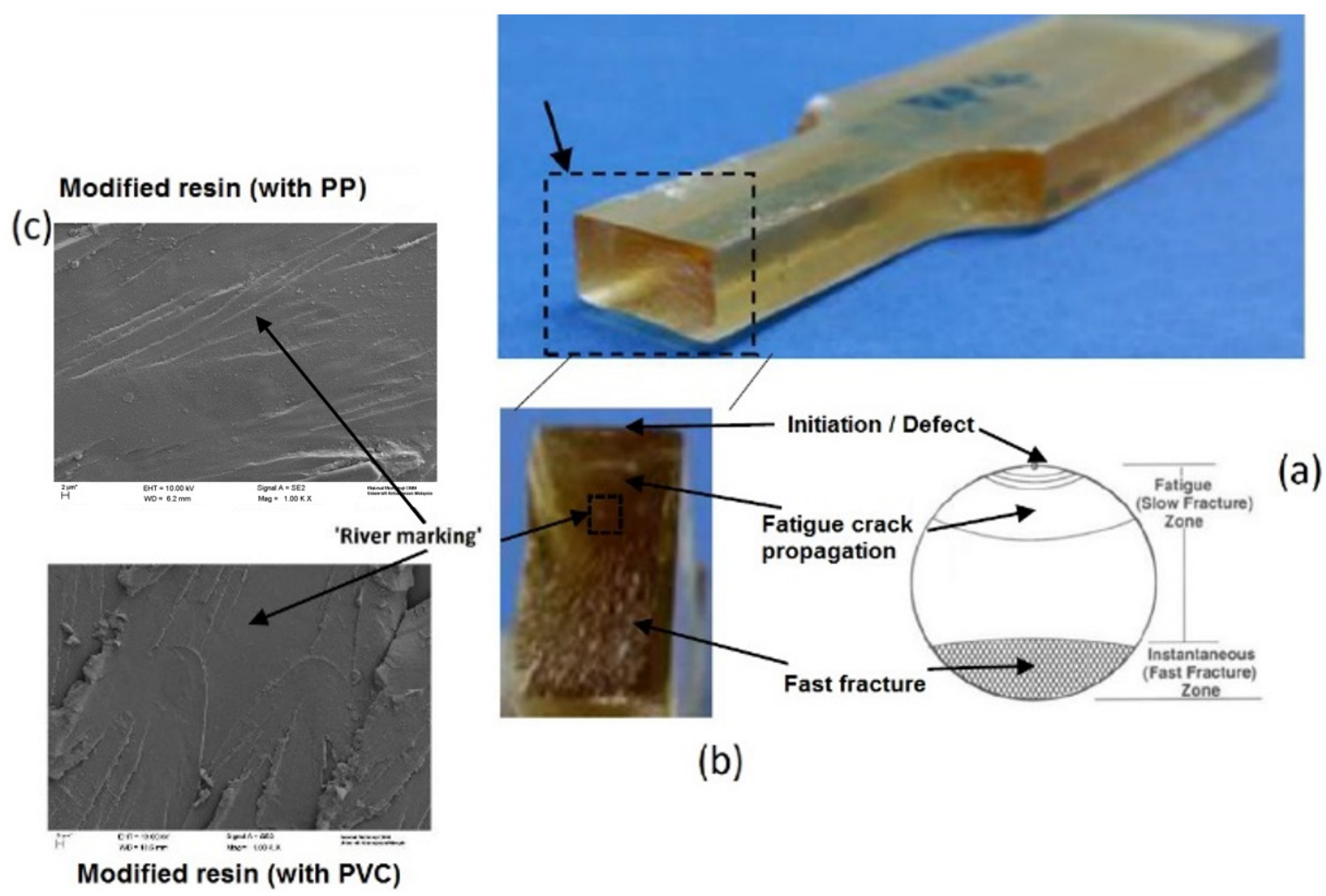

(b)

FIGURE 12. The (a) schematic, (b) micrograph and (c) SEM image of the fatigue fracture surface of modified resin specimen that is completely broken 
TABLE 1. Corrected healing efficiency $\left(\mathrm{H}_{\mathrm{K}}\right)$ of the healable resin obtained from compact tension data were being calculated; in which five replicate tests were conducted for each set of material

\begin{tabular}{cccc}
\hline \multirow{2}{*}{ Sample } & \multicolumn{3}{c}{ Healing efficiency, $\mathrm{H}_{\mathrm{K}}(\%)$} \\
\cline { 2 - 4 } & $1^{1^{\text {st }}}$ healing cycle & $2^{\text {nd }}$ healing cycle & $3^{\text {rd }}$ healing cycle \\
\hline Modified resin (PVC) & 75 & 54 & 48 \\
Modified resin (PP) & 67 & 42 & 36 \\
Modified resin (PE) & 52 & 44 & 32 \\
Modified resin (PVA) & 46 & 38 & 31 \\
\hline
\end{tabular}

TABLE 2. Summary data for the number of cycles of fatigue testing required until the material fails (average data from 5 sample for each resin)

\begin{tabular}{ccc}
\hline \multicolumn{2}{c}{ Sample } & The number of cycles, N \\
\hline Neat (control) resin & Without healing & 2098 \\
Modified resin (with PVC) & 1946 \\
Modified resin (with PP) & & 1860 \\
Modified resin (with PVC) & With 4/5 times healing cycle & 3377 \\
Modified resin (with PP) & & 2886 \\
\hline
\end{tabular}

TABLE 3. Residue strength of neat and modified resin after fatigue cycles or/and healing process (average data from 5 sample for each resin)

\begin{tabular}{|c|c|c|c|c|}
\hline Specimen & $\begin{array}{l}\text { Fatigue } \\
\text { cycles, N }\end{array}$ & $\begin{array}{l}\text { Average UTS } \\
(\mathrm{MPa}), \sigma_{\mathrm{o}}\end{array}$ & $\begin{array}{l}\text { Average residue tensile strength } \\
(\mathrm{MPa}), \sigma_{\mathrm{f}} \text { after fatigue cycles }\end{array}$ & $\begin{array}{l}\text { Average residue tensile strength } \\
(\mathrm{MPa}), \sigma_{\mathrm{f}} \text { after healing process }\end{array}$ \\
\hline \multirow[t]{3}{*}{ Neat resin } & 600 & 40.2 & 26.2 & - \\
\hline & 600 & 37.2 & 23.6 & 34.2 \\
\hline & 1200 & - & - & 24.1 \\
\hline \multirow[t]{5}{*}{$\begin{array}{l}\text { Modified resin } \\
\text { (with PP) }\end{array}$} & 1800 & - & - & 21.4 \\
\hline & 2400 & - & - & 19.8 \\
\hline & 3000 & - & & - \\
\hline & 600 & 40.8 & 24.1 & 36.3 \\
\hline & 1200 & - & & 25.2 \\
\hline \multirow[t]{3}{*}{$\begin{array}{l}\text { Modified resin } \\
\text { (with PVC) }\end{array}$} & 1800 & - & & 23.9 \\
\hline & 2400 & - & & 22.4 \\
\hline & 3000 & - & & 20.0 \\
\hline
\end{tabular}




\section{CONCLUSION}

Under the fatigue test, the fatigue life of modified resin containing PVC or PP was shown to be increased by a factor 1.5 and 1.1 compared to the control resin's fatigue life (without a healing agent). The healable (modified) resin also showed an improvement in residual strength than the control resin after exposure to fatigue cycles. In the healing process, the heterogeneous resin blend undergoes a volumetric thermal expansion of healing agent within the matrix resin for crack recovery. The fatigue-healing process was proven through the surface and cross-section resin morphology analyses using microscopy optic and SEM. The results obtained from this study confirmed that the heterogeneous solid-state self-healing resin system; is capable in obstructing fatigue crack propagation and monotonic fracture, thus effectively provides a self-healing polymer material with higher endurance limits or durability.

\section{ACKNOWLEDGEMENTS}

The authors acknowledged the financial support of this study by the Government of Malaysia through the grant number of GGP-2017-086. The authors also wish to thank the Department of Chemical Sciences, Faculty of Science and Technology and the Department of Mechanical and Engineering, Faculty of Engineering and Architecture, National University of Malaysia for the facilities and support of this project.

\section{REFERENCES}

Anja, G., Michael, B., Pavel, H., Ondrej, S. \& Gerald, P. 2020. Mixed mode I/III fatigue fracture characterization of polyoxymethylene. International Journal of Fatigue 130: 245-269.

ASTM-D638. 2003. Standard Test Method for Tensile Properties of Plastics. American Society for Testing and Materials.

ASTM-D3479M. 2003. Standard Test Method for TensionTension Fatigue of Polymer Matrix Composite Materials. American Society for Testing and Materials.

Awaja, F., Zhang, S., Tripathi, M., Nikiforov, A. \& Pugno, N. 2016. Cracks, microcracks and fracture in polymer structures: Formation, detection, autonomic repair. Progress in Materials Science 83: 536-573.

Blaiszik, B.J., Kramer, L.B., Olugebefola, S.C., Moore, J.S., Sottos, N.R. \& White, S.R. 2010. Self-healing polymers and composites. Annual Review of Materials Research 40: 179-211.

Brown, E.N., White, S.R. \& Sottos, N.R. 2005. Retardation and repair of fatigue cracks in a microcapsule toughened epoxy composite- Part II: In situ self-healing. Composites Science and Technology 65(15-16): 2474-2480.

BS-13586. 2000. Plastics- Determination of Fracture Toughness $\left(G_{1 C}\right.$ and $\left.K_{l C}\right)$ - Linear Elastic Fracture Mechanics (LEFM) Approach. British Standards Institute.

Gyarmati, B., Szilágyi, B.Á. \& Szilágyi, A. 2017. Reversible interactions in self-healing and shape memory hydrogels. European Polymer Journal 93: 642-669.
Hamilton, A.R., Sottos, N.R. \& White, S.R. 2012. Mitigation of fatigue damage in self-healing vascular materials. Polymer 53(24): 5575-5581.

Hayes, S.A., Jones, F.R., Marshiya, K. \& Zhang, W. 2007. A self-healing thermosetting composite material. Composites A: Applied Science and Manufacturing 38(4): 1116-1120.

Hirschberg, V., Lacroix, F., Wilhelm, M. \& Rodrigue, D. 2019. Fatigue analysis of brittle polymers via Fourier transform of the stress. Mechanics of Materials 137: 103-110.

Jamil, M.S.M., Jones, F.R., Muhammad, N.N. \& Makenan, S.M. 2015a. Solid-state self-healing systems: The diffusion of healing agent for healing recovery. Sains Malaysiana 44(6): 843-852.

Jamil, M.S.M., Makenan, S.M., Muhamad, N.N., Lazim, A.M. \& Jones, F. 2015b. Mechanistic studies of solid state selfhealing systems. Malaysian Journal of Analytical Sciences 19(2): 428-436.

Kanu, N.J., Gupta, E., Vates, U.K. \& Singh, G.K. 2019. Selfhealing composites: A state-of-the-art review. Composites Part A: Applied Science and Manufacturing 121: 474-486.

Katunin, A. \& Wronkowicz, A., 2017. Evolution of a fracture mechanism in a polymeric composite subjected to fatigue with the self-heating effect. Procedia Structural Integrity 5: 416-421.

Kim, S.Y., Sottos, N.R. \& White, S.R. 2019. Self-healing of fatigue damage in cross-ply glass/epoxy laminates. Composites Science and Technology 175: 122-127.

Kostopoulos, V., Kotrotsos, A., Sousanis, A. \& Sotiriadis, G. 2019. Fatigue behaviour of open-hole carbon fibre/epoxy composites containing bis-maleimide based polymer blend interleaves as self-healing agent. Composites Science and Technology 171: 86-93.

Kullmer, G., Reschetnik, W., Schramm, B. \& Richard, H.A. 2016. Fatigue crack growth near regions with differing stiffness. Procedia Structural Integrity 2: 2994-3001.

Lee, M.W., An, S., Yoon, S.S. \& Yarin, A.L. 2018. Advances in self-healing materials based on vascular networks with mechanical self-repair characteristics. Advances in Colloid and Interface Science 252: 21-37.

Luo, X.F., Ou, R.Q., Eberly, D.E., Singhal, A., Viratyaporn, W. \& Mather, P.T. 2009. A thermoplastic/thermoset blend exhibiting thermal mending and reversible adhesion. ACS Applied Materials \& Interfaces 1(3): 612-620.

Meure, S., Varley, R.J., Wu, D.Y., Mayo, S., Nairn, K. \& Furman, S. 2012. Confirmation of the healing mechanism in a mendable EMAA-epoxy resin. European Polymer Journal 48(3): 524-531.

Michael, B., Hartmut, R.F. \& Santiago, J.G. 2019. Self-healing polymeric systems: Concepts and applications. In Smart Polymers and their Applications, edited by Maria, R.A. \& Julio, S.R. New York: Woodhead Publishing.

Muhamad, N.N. \& Jamil, M.S. 2016. Homogeneous and heterogeneous solid state self-healing system. Polymers and Polymer Composites 24(9): 815-824.

Murphy, E.B. \& Wudl, F. 2010. The world of smart healable materials. Progress in Polymer Science 35(2): 223-251.

Sharma, J., Tewari, K. \& Arya, R.K. 2017. Diffusion in polymeric systems - A review on free volume theory. Progress in Organic Coatings 111: 83-92. 
Skinner, T., Datta, S., Chattopadhyay, A. \& Hall, A. 2019. Fatigue damage behavior in carbon fiber polymer composites under biaxial loading. Composites Part B: Engineering 174: 936942.

Urdl, K., Kandelbauer, A., Kern, W., Müller, U., Thebault, M. \& Zikulnig-Rusch, E. 2017. Self-healing of densely crosslinked thermoset polymers - A critical review. Progress in Organic Coatings 104: 232-249.

Ye, X.J., Zhu, Y., Yuan, Y.C., Song, Y.X., Yang, G.C., Rong, M.Z. \& Zhang, M.Q. 2017. Improvement of fatigue resistance of epoxy composite with microencapsulated epoxy- $\mathrm{SbF}_{5}$ selfhealing system. Express Polymer Letters 11(11): 853-862.

Zhang, C., Wang, H. \& Zhou, Q. 2018. Preparation and characterization of microcapsules based self-healing coatings containing epoxy ester as healing agent. Progress in Organic Coatings 125: 403-410.
Zhang, P. \& Li, G. 2016. Advances in healing-on-demand polymers and polymer composites. Progress in Polymer Science 57: 32-63.

Department of Chemical Sciences

Faculty of Science and Technology

Universiti Kebangsaan Malaysia

43600 UKM Bangi, Selangor Darul Ehsan

Malaysia

*Corresponding author; email: suzeren@ukm.edu.my

Received: 15 October 2019

Accepted: 8 May 2020 